\title{
ECOLOGICAL STUDIES OF ENZOOTIC VENEZUELAN EQUINE ENCEPHALITIS IN NORTH-CENTRAL VENEZUELA, 1997-1998
}

\author{
ROSA ALBA SALAS, CARMEN Z. GARCIA, JONATHAN LIRIA, ROBERTO BARRERA, JUAN CARLOS NAVARRO, \\ GLADYS MEDINA, CLOVIS VASQUEZ, ZORAIDA FERNANDEZ, AND SCOTT C. WEAVER \\ Instituto Nacional de Higiene, Caracas, Venezuela; Instituto de Zoologia Tropical, Universidad Central de Venezuela, \\ Caracas, Venezuela; Instituto de Investigaciones Veterinarias, Maracay, Venezuela; Center for Tropical Diseases and \\ Department of Pathology, University of Texas Medical Branch, Galveston, Texas
}

\begin{abstract}
From 1997-1998, we investigated the possible continuous circulation of epizootic Venezuelan equine encephalitis (VEE) virus suggested by a 1983 subtype IC interepizootic mosquito isolate made in Panaquire, Miranda State, Venezuela. The study area was originally covered by lowland tropical rainforest but has been converted into cacao plantations. Sentinel hamsters, small mammal trapping, mosquito collections, and human serosurveys were used to detect active or recent virus circulation. Six strains of subtype ID VEE virus were isolated from hamsters that displayed no apparent disease. Four other arboviruses belonging to group A (Togaviridae: Alphavirus), two Bunyamwera group (Bunyaviridae), and three Gamboa group (Bunyaviridae) arboviruses were also isolated from hamsters, as well as 8 unidentified viruses. Venezuelan equine encephalitis-specific antibodies were detected in 5 small mammal species: Proechimys guairae, Marmosa spp., and Didelphis marsupialis. Mosquito collections comprised of 38 different species, including 8 members of the subgenus Culex (Melanoconion), did not yield any virus isolates. Sera from 195 humans, either workers in the cacao plantation or nearby residents, were all negative for VEE virus antibodies. Sequences of 1,677 nucleotides from the P62 gene of 2 virus isolates indicated that they represent a subtype ID lineage that is distinct from all others characterized previously, and are unrelated to epizootic VEE emergence.
\end{abstract}

\section{INTRODUCTION}

Venezuelan equine encephalitis (VEE) is a zoonotic arboviral disease that affects equines and humans in the Americas. $^{1-3}$ Venezuelan equine encephalitis virus has caused devastating outbreaks since the early years of the twentieth century. After Kubes and Rios identified and characterized VEE virus in $1938,{ }^{4}$ an inactivated vaccine was prepared to control the disease. However, major epizootics and epidemics continued in Colombia, Venezuela, Trinidad, and Peru between 1955-19595; another large epizootic/epidemic occurred in Colombia, Venezuela, Ecuador, and Peru between 1962 and 1969, and another major outbreak began in Guatemala on the Pacific coast and spread through much of Central America, Mexico, and into Texas in 1971. Each of these epidemics and epizootics was characterized by a rapid spread, covering vast geographic areas and affecting large numbers of susceptible equines and humans. Virus activity and disease ceased when the number of susceptible equines decreased due to mortality and herd immunity. ${ }^{1-3,5}$

Venezuelan equine encephalitis epidemics and epizootics were not reported between 1973 and December 1992, when a small human and equine outbreak occurred in the Trujillo and Zulia States of Venezuela. ${ }^{6}$ Subsequent outbreaks have been reported during the 1990s in Mexico ${ }^{7}$ and Peru, but the largest epidemic/epizootic occurred between April and December 1995, affecting hundreds of thousands of equines and humans in northern Venezuela and Colombia. ${ }^{9,10}$ The 1995 outbreak had many similarities to the one that occurred from 1962-1964: first, cases occurred in the same regions of Venezuela and Colombia, and the epicenter was in the Guajira peninsula; second, the VEE virus subtype IC strains isolated in both outbreaks are nearly identical genetically. ${ }^{9}$

Venezuelan equine encephalitis viruses are mosquitoborne RNA viruses belonging to family Togaviridae, genus Alphavirus, which includes seven antigenic complexes. ${ }^{11}$ The VEE antigenic complex includes six antigenic subtypes and additional antigenic varieties, but only subtypes IAB and IC are pathogenic for horses and produce high titered viremia sufficient for efficient epizootic amplification. These IAB and IC viruses have generally been isolated only during epizootics. Subtype I, varieties D through F, and subtypes II through VI are generally equine avirulent and circulate in enzootic cycles in tropical forests and swamps of South, Central, and North America, where they occasionally cause human disease but never major outbreaks. ${ }^{1-3}$

For many years, the source of epidemic/epizootic, subtype IAB and IC viruses remained unknown. Phylogenetic studies of VEE viruses isolated during the 1992-1993 outbreak in Venezuela support the hypothesis of periodic emergence of epizootic viruses via mutations of enzootic strains. ${ }^{6,12,13}$ However, the close relationship between a subtype IC virus strain isolated from a mosquito pool during an interepidemic period in 1983 (Panaquire strain), ${ }^{14}$ and other IC strains isolated in Venezuela during the 1962-1964 and 1995 outbreaks, suggest a silent, continuous transmission cycle of epizootic viruses in northern Venezuela. ${ }^{13}$ To investigate this possibility, we conducted arbovirus surveillance in Panaquire, the locality where the 1983 IC strain was isolated.

\section{MATERIALS AND METHODS}

Study area. The study was carried out from 1997-1998 in north-central Venezuela (Figure 1) at Padrón Agriculture Station, Ministry of Agriculture, (10 $13^{\prime} 22^{\prime \prime} \mathrm{N} ; 66^{\circ} 17^{\prime} 56^{\prime \prime} \mathrm{W}$; $50 \mathrm{~m}$ elevation) in Miranda State, Venezuela. This area was originally covered by lowland tropical rainforest that has been converted into cacao plantations (Theobroma cacao). Tall trees providing shade for the cacao plantation (Erythrina poeppigiana, Ceiba pentandra, Ficus sp., Hura crepitans, Bauhinia sp.), have been preserved and, together with the cacao trees, resemble a natural forest habitat. Tall, herbaceous Heliconia spp. and Calathea sp. are abundant at the 


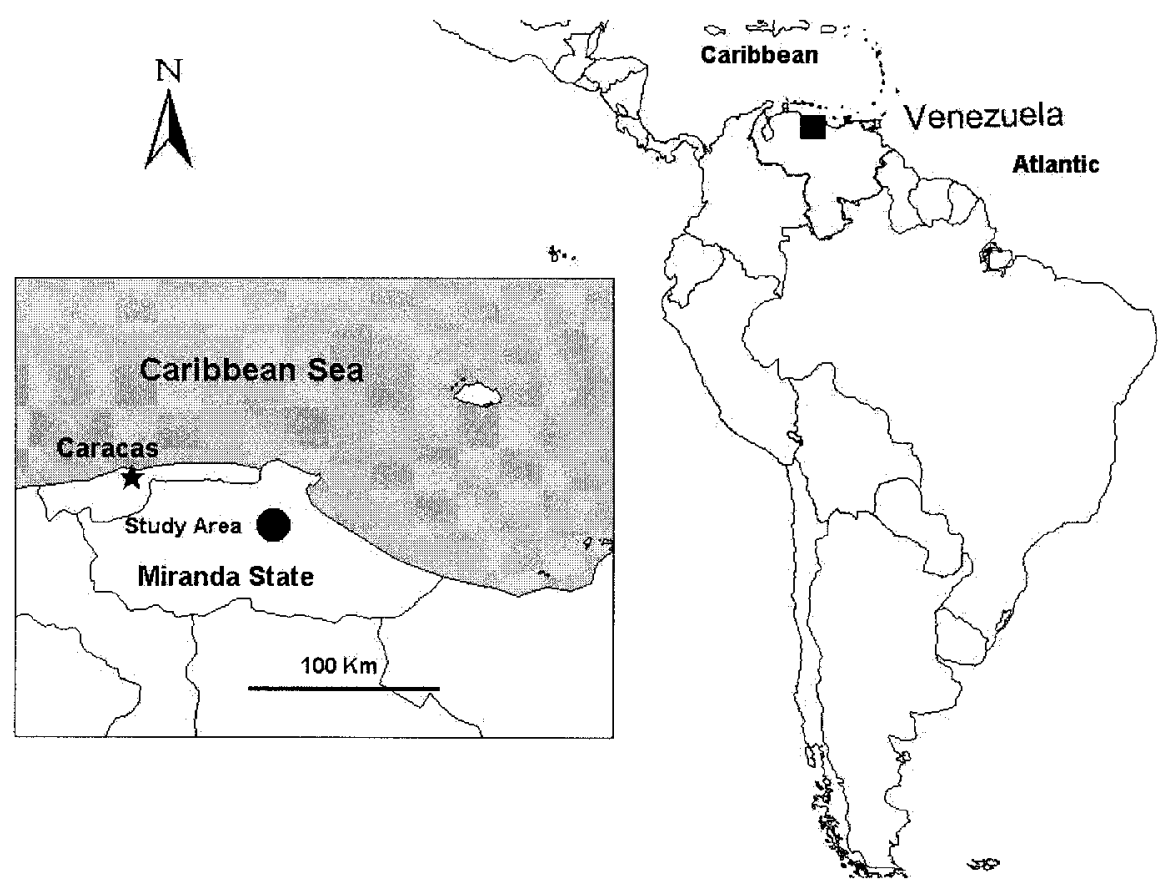

FIGURE 1. Map showing the location of the study site.

forest edges or along secondary streams. The area is periodically flooded by the Tuy River, and the study site is within $1 \mathrm{~km}$ of the river. Mean temperature and annual rainfall were $27.2^{\circ} \mathrm{C}$ and $2,324 \mathrm{~mm}$, respectively (1992-1998) at the field station (Padrón Meteorological Station, FONAIAP). The rainy season lasts from May to December, with decreasing rains in September and October (Figure 2). The dry season of 1997-1998 began earlier than usual (December 1997), and 1998 was a relatively dry year with less rain $(1,936.8 \mathrm{~mm})$ and a higher mean temperature $\left(28.1^{\circ} \mathrm{C}\right)$ than in previous years.

Field studies. Venezuelan equine encephalitis virus surveillance was conducted in the study area during 6 field trips between May 1997 and September 1998 (Table 1).

Sentinel animals. Syrian golden hamsters from a colony at the Instituto Nacional de Higiene in Caracas were exposed for 7 days at the cacao plantation to mosquito bites in "coquito" cages constructed from paint cans ${ }^{15}$ for 7 days in the

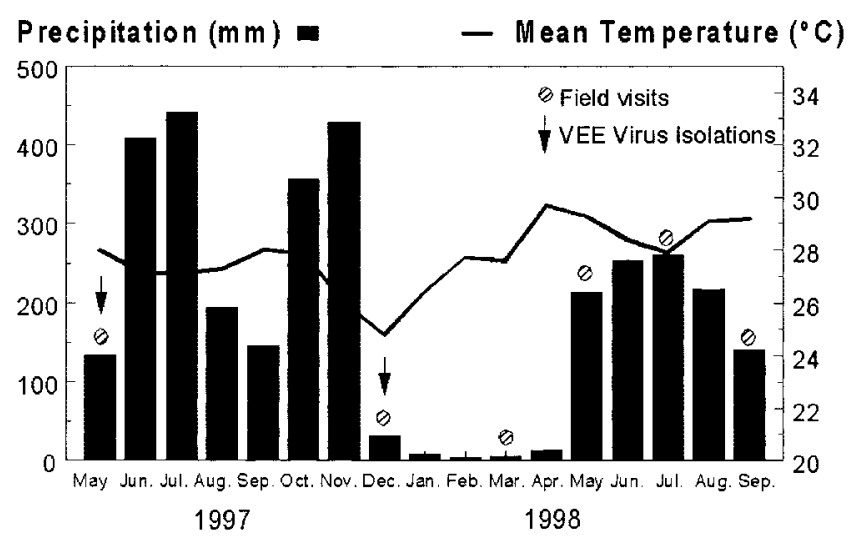

FIGURE 2. Precipitation, temperature, and virus isolation data for the study period. VEE = Venezuelan equine encephalitis virus. cacao plantation. Each cage contained a pair of sentinel hamsters so that if one of the animals became sick, the other one could be examined for earlier stages in the development of the disease and viremia. On each field visit, 40 cages were suspended 1.2-1.5 $\mathrm{m}$ above the ground and placed in transects at $25 \mathrm{~m}$ intervals. Hamsters were inspected and fed carrots and rat chow early each morning. Blood samples were collected by cardiac puncture from sick hamsters and from those surviving the 1-week exposure, then the hamsters were killed. Heart and spleen samples from hamsters found dead during the exposure period were dissected and preserved in liquid nitrogen. The maintenance and care of experimental animals complied with the Venezuelan National Institute of Hygiene guidelines for the humane use of laboratory animals.

Collection of small mammals. Parallel to the transect where sentinel hamsters were exposed, we placed 40-45 Sherman (H. B. Sherman Traps, Inc., Tallahassee, FL) and 20-30 Tomahawk (Tomahawk Trap Company, Tomahawk, WI) traps for 7-10 days. Bait for the Sherman traps was replaced every day and consisted of a mixture of sardines, corn flour, corn grains, bird food, peanut butter, vanilla extract, and vegetable oil. Ripe plantains and cassava were used as bait in the Tomahawk traps. Captured animals were bled by cardiac puncture, and those which could not be readily identified were preserved with formaldehyde and placed in plastic bags with $80 \%$ ethanol. Blood samples and organs were collected as described above.

Collection of mosquitoes. Mosquitoes were collected in December 1997 and in March, July, and September 1998 using miniature Centers for Disease Control and Prevention light traps (John W. Hock Company, Gainesville, FL) baited with $\mathrm{CO}_{2}$. We operated $3 \mathrm{CDC}$ traps for 3-4 days, collecting during the day (6 AM-6 PM) and night (6 PM-6 AM). Dry ice was suspended near the trap opening and replaced every 
TABLE 1

Distribution of arboviruses isolated from sentinel hamsters in the Padrón Agriculture Station, Tapipa, Miranda State, 1997-1998

\begin{tabular}{|c|c|c|c|c|c|c|c|}
\hline \multirow[b]{2}{*}{ Month } & \multicolumn{3}{|c|}{ Number of sentinel hamsters } & \multicolumn{2}{|c|}{ Alphaviruses } & \multirow[b]{2}{*}{ Bunyaviruses } & \multirow[b]{2}{*}{$\begin{array}{c}\text { Unknown } \\
\text { viruses }\end{array}$} \\
\hline & Exposed & $\begin{array}{l}\text { Moribund } \\
\text { or dead }\end{array}$ & Lost & VEE & Other & & \\
\hline May 1997 & 80 & 3 & 1 & 2 & 0 & 0 & 1 \\
\hline December 1997 & 80 & 3 & 0 & 4 & 3 & 2 & 4 \\
\hline March 1998 & 80 & 11 & 0 & 0 & 0 & 0 & 0 \\
\hline May 1998 & 80 & 5 & 0 & 0 & 0 & 0 & 0 \\
\hline July 1998 & 80 & 30 & 0 & 0 & 1 & 0 & 3 \\
\hline September 1998 & 80 & 2 & 1 & 0 & 0 & 3 & 0 \\
\hline Total & 480 & 54 & 2 & 6 & 4 & 5 & 8 \\
\hline
\end{tabular}

$\mathrm{VEE}=$ Venezuelan equine encephalitis virus

$12 \mathrm{hr}$. One CDC trap was placed outside the cacao plantation in an open area $100 \mathrm{~m}$ from the edge of the plantation, and the other 2 were placed along a transect 10 and $200 \mathrm{~m}$ inside the plantation. Mosquitoes were frozen in liquid nitrogen and transported to the laboratory for identification. Mosquitoes collected during December 1997 were also processed for virus isolations. Pools of individual species containing 1-40 individuals were ground in a tissue grinder containing 1.0 $\mathrm{ml}$ of Eagles minimum essential medium (MEM) supplemented with $20 \%$ fetal bovine serum, penicillin, streptomycin, and Fungizone. The triturated pool was centrifuged for $5 \mathrm{~min}$ at $10,000 \times \mathrm{g}$, and a $200 \mu \mathrm{l}$ volume was added to a $10 \mathrm{ml}$ plastic tube containing a monolayer of Vero cells and $2 \mathrm{ml}$ of MEM. Cultures were monitored for cytopathic effects for 7 days.

Epidemiological studies. A retrospective cohort serosurvey of VEE infection was undertaken in human and animal populations. Three human populations which had resided in the study area for many years were selected, based on the degree of VEE infection risk: 31 workers from the Padrón Experimental Station were considered at high risk because of their labor in the cacao plantation; 141 persons from Tapipa, located approximately $1.5 \mathrm{~km}$ from the forest, were considered at intermediate risk of VEE virus infection, and 29 persons from Panaquire, located approximately $7 \mathrm{~km}$ from the study area, were considered at lower risk of VEE virus infection. The demographic characteristics are described in Table 2.

A seroprevalence study was also conducted in 224 surviving sentinel hamsters exposed in the field, 53 horses with-

\section{TABLE 2}

Human populations sampled for Venezuelan equine encephalitis virus antibodies

\begin{tabular}{llccc}
\hline & & \multicolumn{3}{c}{ Locality } \\
\cline { 3 - 5 } \multicolumn{1}{c}{ Demographic characteristics } & $\begin{array}{c}\text { Padrón } \\
\text { Agriculture } \\
\text { Station }\end{array}$ & Tapipa & Panaquire \\
\hline Age (yr) & $5-10$ & 0 & 32 & 2 \\
& $11-20$ & 1 & 65 & 8 \\
\multirow{5}{*}{ Sex } & $21-40$ & 10 & 18 & 9 \\
\multirow{3}{*}{ Occupation } & $>40$ & 20 & 25 & 10 \\
& Male & 31 & 55 & 7 \\
& Female & 0 & 85 & 22 \\
& Farmer & 31 & 6 & 3 \\
& Housekeeper & 0 & 27 & 20 \\
& Student & 0 & 97 & 3 \\
& Other & 0 & 10 & 3 \\
\hline
\end{tabular}

out any history of vaccination residing in farms near the study area, and 63 wild animals captured during the study period.

Virology studies. In order to determine the incidence of VEE virus infection in the study area, virology studies were undertaken in febrile patients (with or without neurologic manifestations) residing near the study area. Field and clinical specimens (including blood, heart, and spleen homogenates) were inoculated in plastic tubes with monolayer cultures of Vero cells. Infected cultures that developed cytopathic effects were harvested and a suspension of infected cells was placed on 12-well spot slides. After the cells were dried, they were fixed in cold acetone and examined for the presence of arbovirus antigens by immunofluorescent assay (IFA) using hyperimmune mouse ascitic fluid against the following groups of arboviruses: A, B, C, Bunyamwera, Capin, Guaroa, and Simbú (reference reagents from National Institutes of Health). Immunofluorescent assay-positive cultures to group A arboviruses were subtyped using monoclonal antibodies described previously. ${ }^{16}$ The hemagglutination inhibition method was used for antibody detection using eastern equine encephalitis (EEE) and VEE virus antigens.

Sequencing and phylogenetic analyses. Nucleotide sequences of reverse transcription-polymerase chain reaction (RT-PCR) products totaling 1,677 base pairs, excluding the terminal primers, were generated for the complete P62 gene as described previously. ${ }^{17}$ Viral RNA was extracted from the supernatant of first passage Vero cell stocks using Trizol LS (Bethesda Research Laboratories, Bethesda, MD) according to the manufacturer's protocol. The RT-PCR protocol and primers were described previously. ${ }^{17}$ Nucleotide sequences generated directly from amplicons using the Applied Biosystems (Foster City, CA) Prism sequencing kit and 377 sequencer, according to the manufacturer's protocol, were aligned using the PILEUP program ${ }^{18}$ in the Wisconsin Package (Genetics Computer Group, Madison, WI) with default settings. Phylogenetic analyses were performed using the complete 1,677 nucleotide amplicon sequences with maximum likelihood, maximum parsimony and neighbor joining programs implemented in PAUP 4.0 (Sinauer Associates, Sunderland, MA). ${ }^{19}$ The maximum likelihood model included a transition:transversion ratio of $4: 1-5: 1$ and a gamma distribution of 0.25 , based on empirical alphavirus estimates. $^{20-22}$ Bootstrapping ${ }^{23}$ was performed to place confidence estimates on selected clades within trees. The outgroup consisted of representative homologous sequences of four major lineages of EEE virus. ${ }^{24}$ 
TABLE 3

Small mammals captured and prevalence of hemagglutination inhibition antibodies to Venezuelan equine encephalitis virus in the Padrón Agriculture Station, Tapipa, Miranda State, 1997-1998

\begin{tabular}{|c|c|c|c|c|c|}
\hline Month & Trap type & $\begin{array}{l}\text { No. } \\
\text { trap-nights }\end{array}$ & $\begin{array}{l}\text { Mammal species* } \\
\text { (no. collected) }\end{array}$ & $\begin{array}{l}\text { Fraction } \\
\text { with } \\
\text { antibodies } \dagger\end{array}$ & $\begin{array}{c}\text { Positive } \\
\text { antibody titers }\end{array}$ \\
\hline May 1997 & $\begin{array}{l}\text { Sherman } \\
\text { Tomahawk }\end{array}$ & 210 & $\begin{array}{l}\text { Marmosa murina }(1) \\
\text { Zygodontomys microtunus }(2) \\
\text { Didelphis marsupialis }(3) \\
\text { Oryzomys talamancae }(1) \\
\text { Proechimys guairae }(5)\end{array}$ & $\begin{array}{l}0 / 1 \\
0 / 2 \\
0 / 3 \\
0 / 1 \\
3 / 5\end{array}$ & $1: 20(2), 1: 10$ \\
\hline December 1997 & Sherman & 400 & $\begin{array}{l}\text { Marmosa sp. (4) } \\
\text { Marmosa cinerea (1) } \\
\text { Oryzomys delicatus (1) } \\
\text { Rat (unidentified) (1) } \\
\text { Didelphis marsupialis (4) } \\
\text { Proechimys guairae (6) } \\
\text { Cricetidae (unidentified) (1) }\end{array}$ & $\begin{array}{l}1 / 4 \\
0 / 1 \\
0 / 1 \\
0 / 1 \\
1 / 4 \\
1 / 6 \\
0 / 1\end{array}$ & $\begin{array}{l}1: 160 \\
1: 160\end{array}$ \\
\hline March 1998 & Sherman & 400 & $\begin{array}{l}\text { Monodelphis brevicaudata (3) } \\
\text { Marmosa fuscata }(1) \\
\text { Proechimys guairae (1) } \\
\text { Didelphis marsupialis (3) } \\
\text { Marmosa cinerea }(1) \\
\text { Marmosa murina }(1) \\
\text { Proechimys guairae (2) }\end{array}$ & $\begin{array}{l}0 / 3 \\
0 / 1 \\
0 / 1 \\
0 / 3 \\
0 / 1 \\
0 / 1 \\
0 / 2\end{array}$ & \\
\hline May 1998 & Sherman & 410 & $\begin{array}{l}\text { Didelphis marsupialis }(1) \\
\text { Marmosa cinerea }(1) \\
\text { Marmosa fuscata }(2) \\
\text { Marmosa murina }(1) \\
\text { Monodelphis brevicaudata (6) } \\
\text { Zygodontomys microtunus (1) } \\
\text { NC }\end{array}$ & $\begin{array}{l}0 / 1 \\
0 / 1 \\
0 / 2 \\
0 / 1 \\
0 / 6 \\
0 / 1\end{array}$ & \\
\hline July 1998 & $\begin{array}{l}\text { Sherman } \\
\text { Tomahawk }\end{array}$ & $\begin{array}{l}410 \\
190\end{array}$ & $\begin{array}{l}\text { Marmosa fuscata }(1) \\
\text { Oryzomys talamancae (1) } \\
\text { Proechimys guairae (2) }\end{array}$ & $\begin{array}{l}0 / 1 \\
0 / 1 \\
1 / 2\end{array}$ & $1: 10$ \\
\hline August 1998 & $\begin{array}{l}\text { Sherman } \\
\text { Tomahawk }\end{array}$ & $\begin{array}{l}400 \\
290\end{array}$ & $\begin{array}{l}\mathrm{NC} \\
\text { Didelphis marsupialis }(1)\end{array}$ & $0 / 1$ & \\
\hline September 1998 & $\begin{array}{l}\text { Sherman } \\
\text { Tomahawk }\end{array}$ & $\begin{array}{l}400 \\
190\end{array}$ & $\begin{array}{l}\mathrm{NC} \\
\text { Didelphis marsupialis (2) } \\
\text { Proechimys guairae (1) }\end{array}$ & $\begin{array}{l}1 / 2 \\
0 / 1\end{array}$ & $1: 10$ \\
\hline
\end{tabular}

$\dagger \mathrm{NC}=$ no captures.
$\dagger$ Positive titers were considered 1:10 or greater.

Nucleotide sequence accession numbers. The new VEE virus sequences were deposited in the GenBank library under accession numbers AF348335 and AF348336.

\section{RESULTS}

Virus isolations and rodent serology. A total of 480 sentinel hamsters was exposed in the field and 55 (11.5\%) became sick or died. From these 55 animals, 23 virus strains were isolated. Table 1 shows the time distribution of arboviruses isolated during the study period. Six of the isolates were identified as VEE virus subtype ID, 4 as other arboviruses belonging to group A (Alphavirus genus), 2 as Bunyamwera group (Bunyaviridae), and 3 as Gamboa group (Bunyaviridae); 8 viruses could not be identified. Venezuelan equine encephalitis viruses were only isolated during May and December of 1997, and all isolates came from the serum of animals with no apparent disease. This suggests that, unlike most other VEE complex viruses, these strains may be avirulent for hamsters. No isolates of VEE or other arboviruses were made from febrile patients during the study period.
A total of 63 small mammals was collected during 2,952 trap-nights, for a success rate of $2 \%$. The species captured and the results of the virology studies are shown in Table 3. Proechimys guairae (17) and Didelphis marsupiales (14) were abundant throughout the study period. There was no virus isolation from wild mammal specimens, but $\mathrm{HI}$ antibodies to VEE virus were detected in 5 of 17 (29\%) of the Proechimys guairae captured. Venezuelan equine encephalitis antibodies were also detected in Marmosa spp. (1 of 4), Didelphis marsupialis (2 of 14) and Monodelphis brevicaudata (1 of 4). The HI antibody titers ranged from 1:10-1: 160 , and the positive animals were captured in May of 1997 , and in July and September of 1998. No viruses were isolated from the captured animals.

Mosquito collections. A total of 38 mosquito species was collected with the $\mathrm{CO}_{2}$-baited CDC light traps (Table 4). Mean numbers of mosquitoes captured per 12-hour interval were lowest in March and May 1998. These months correspond to the dry season and the beginning of the rainy season in the study area (Figure 2). Maximum catches were obtained in July 1998, which is the middle of the first part of the rainy season. The most abundant species captured in 
TABLE 4

Mean number of mosquitoes per Centers for Disease Control and Prevention miniature light/ $\mathrm{CO}_{2}$ trap (12-hour catch) per month

\begin{tabular}{|c|c|c|c|c|c|c|}
\hline \multirow[b]{2}{*}{ Species } & \multicolumn{6}{|c|}{ Month and year } \\
\hline & Dec 1997 & Mar 1998 & May 1998 & Jul 1998 & Sept 1998 & Mean \\
\hline Aedes aegypti & 0.00 & 0.04 & 0.00 & 0.00 & 0.00 & 0.01 \\
\hline Aedes fulvus & 64.04 & 0.00 & 4.78 & 53.67 & 4.44 & 25.39 \\
\hline Aedes scapularis & 0.08 & 0.04 & 0.17 & 3.06 & 4.50 & 1.57 \\
\hline Aedes serratus & 79.50 & 0.04 & 1.33 & 254.00 & 47.50 & 76.48 \\
\hline Anopheles pseudopunctipennis & 1.21 & 0.04 & 0.56 & 0.50 & 0.06 & 0.47 \\
\hline Coquillettidia juxtamansonia & 0.00 & 2.17 & 0.06 & 0.00 & 4.67 & 1.38 \\
\hline Coquillettidia nigricans & 0.88 & 0.04 & 0.00 & 7.11 & 0.17 & 1.64 \\
\hline Coquillettidia venezuelensis & 36.83 & 0.00 & 0.00 & 0.50 & 0.00 & 7.47 \\
\hline Culex (Aed.) amazonensis & 0.63 & 0.17 & 0.11 & 5.11 & 6.33 & 2.47 \\
\hline Culex (Cux.) declarator & 0.50 & 0.38 & 0.00 & 0.00 & 0.50 & 0.28 \\
\hline Culex (Cux.) mollis & 0.96 & 2.38 & 4.83 & 67.44 & 11.33 & 17.39 \\
\hline Culex (Cux.) nigripalpus & 0.50 & 0.00 & 0.00 & 7.61 & 2.72 & 2.17 \\
\hline Culex (Mel.) atratus & 0.04 & 0.00 & 0.00 & 0.00 & 0.00 & 0.01 \\
\hline Culex (Mel.) dunni & 6.04 & 8.63 & 7.50 & 2.78 & 12.89 & 7.57 \\
\hline Culex (Mel.) erraticus & 0.13 & 0.58 & 0.00 & 56.00 & 0.00 & 11.34 \\
\hline Culex (Mel.) gnomatos & 0.00 & 0.00 & 0.00 & 0.11 & 0.00 & 0.02 \\
\hline Culex (Mel.) ocossa & 0.08 & 0.00 & 0.22 & 3.50 & 0.33 & 0.83 \\
\hline Culex (Mel.) pedroi & 25.75 & 0.13 & 0.78 & 4.78 & 10.89 & 8.46 \\
\hline Culex (Mel.) spissipes & 29.38 & 16.42 & 1.78 & 146.56 & 176.50 & 74.13 \\
\hline Culex (Mel.) vomerifer & 1.29 & 0.00 & 0.00 & 0.00 & 0.00 & 0.26 \\
\hline Haemagogus celeste & 0.04 & 0.00 & 0.06 & 0.11 & 0.00 & 0.04 \\
\hline Johnbelkinia ulopus & 0.58 & 0.50 & 0.00 & 0.61 & 0.61 & 0.46 \\
\hline Limatus asulleptus & 5.21 & 0.08 & 0.22 & 12.06 & 0.83 & 3.68 \\
\hline Limatus durhami & 1.46 & 0.08 & 0.83 & 7.06 & 0.22 & 1.93 \\
\hline Mansonia pseudotitillans & 0.00 & 0.00 & 0.00 & 0.00 & 0.06 & 0.01 \\
\hline Mansonia sp. & 0.00 & 1.00 & 1.39 & 0.50 & 1.67 & 0.91 \\
\hline Mansonia titillans & 1.00 & 8.54 & 0.17 & 3.28 & 133.61 & 29.32 \\
\hline Orthopodomyia fuscipes & 0.00 & 0.00 & 0.11 & 13.44 & 0.00 & 2.71 \\
\hline Psorophora albigenu & 0.00 & 0.00 & 0.00 & 0.94 & 0.22 & 0.23 \\
\hline Psorophora albipes & 1.83 & 0.00 & 0.00 & 1.11 & 0.17 & 0.62 \\
\hline Psorophora cingulata & 0.00 & 0.00 & 0.00 & 5.83 & 0.00 & 1.17 \\
\hline Psorophora cyanescens & 0.00 & 0.00 & 0.00 & 2.56 & 0.61 & 0.63 \\
\hline Psorophora ferox & 27.92 & 0.00 & 3.06 & 90.72 & 10.33 & 26.41 \\
\hline Runchomyia magna & 0.54 & 0.00 & 0.00 & 0.00 & 0.00 & 0.11 \\
\hline Sabethes sp. & 0.04 & 0.00 & 0.00 & 0.00 & 0.00 & 0.01 \\
\hline Trichoprosopon digitatum & 0.04 & 0.00 & 0.00 & 0.00 & 0.00 & 0.01 \\
\hline Uranotaenia calosomata & 9.08 & 0.21 & 0.11 & 256 & 0.00 & 2.39 \\
\hline Wyeomyia spp. & 0.83 & 0.00 & 0.00 & 0.00 & 0.00 & 0.17 \\
\hline Total & 296.41 & 41.46 & 28.06 & 753.50 & 431.17 & 310.12 \\
\hline
\end{tabular}

this study were Aedes serratus, Culex (Melanoconion) spissipes, Mansonia titillans, Psorophora ferox, Ae. fulvus, Cx. (Culex) mollis, Cx. (Mel.) erraticus, Cx. (Mel.) pedroi, Cx. (Mel.) dunni, and Coquillettidia venezuelensis (Table 4). During the dry season (March) the most common species were $C x$. (Mel.) spissipes, $C x$. (Mel.) dunni, and Ma. titillans. The most common species in December 1997, when several VEE isolates were obtained, were Ae. serratus, Ae. fulvus, Cq. venezuelensis, Cx. (Mel.) spissipes, Ps. ferox, and Cx. (Mel.) pedroi (Table 4).

No mosquitoes were captured during daylight (6:00 AM6:00 PM) in the open area adjacent to the cacao plantation (Figure 3). The most common species collected during the daytime in the forest (Ae. serratus and Ps. ferox) were also caught at night, although in smaller numbers. Ae. fulvus was also captured during the day, but it was more abundant at night (Figure 3). In general, this species was more common deeper inside the cacao plantation $(200 \mathrm{~m})$. Aedes scapularis was captured mainly in the open area at night, but was also present at 10 and $200 \mathrm{~m}$ inside the cacao plantation throughout the 24-hour period. Typically, diurnal mosquitoes were Limatus asulleptus, Li. durhami, Orthopodomyia fuscipes,
Johnbelkinia ulopus, and Trichoprosopon digitatum (Figure 3). Among the nocturnal species, $C x$. (Mel.) spissipes was the most abundant, especially deeper inside the cacao plantation. A few individuals of this species were captured in the open area at night, but none during the day (Figure 4). Other common, nocturnal mosquitoes, $\mathrm{Cx}$. (Mel.) pedroi and $C x$. (Mel.) dunni, were captured only inside the cacao plantation, whereas $C x$. (Culex) mollis and Cx. (Culex) nigripalpus were also collected in the open area and even during the daytime, deep within the cacao plantation (Figure 4). Mansonia titillans was very common in the open area at night, but a few individuals were also collected inside the plantation throughout the entire 24-hour period (Figure 4). No viruses were isolated from any of the trapped mosquitoes.

Human and equine serology. Sera from 195 humans, either workers at the Padrón Agriculture Station or nearby residents, were all sero-negative by $\mathrm{HI}$ for VEE and EEE viruses. However, HI antibodies to VEE virus were detected in 18 of the 53 horses sampled $(30 \%)$ which may indicate natural infection assuming that as reported by owners, these animals have not been vaccinated against VEE virus.

Antigenic and genetic characterization of VEE virus 


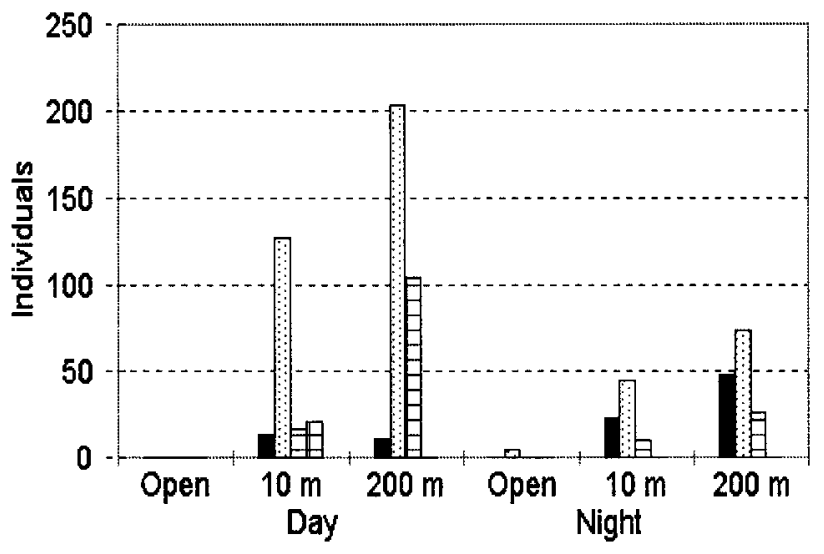

Ae. fulvus 3 Ae serratus $\bigoplus$ Ps ferox 曲 or fuscipes

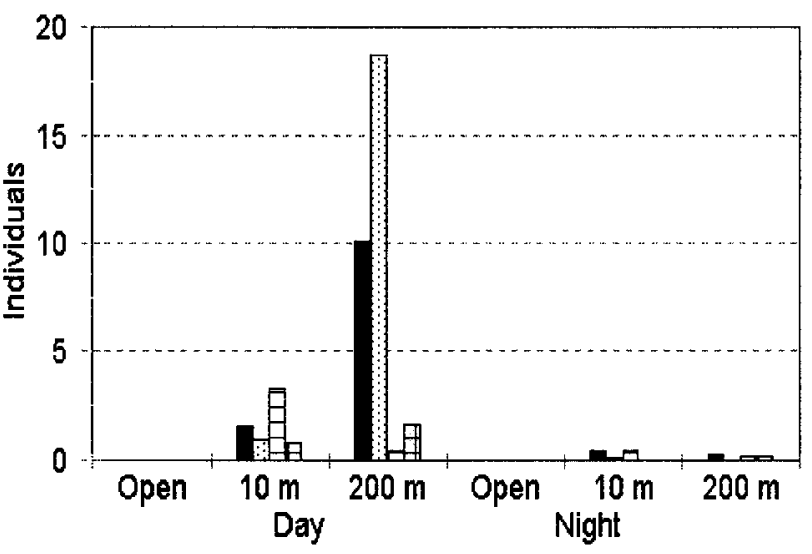

Li. durhami Li. asulleptus $\Theta \mathrm{Tr}$. digitatum 曲 Jo. ulopus

FIGURE 3. Numbers of representative mosquitoes captured in $\mathrm{CO}_{2}$-baited Centers for Disease Control and Prevention light traps outside the forest (open), as well as 10 and $200 \mathrm{~m}$ inside, during the day and at night. Ae. $=$ Aedes; Ps. $=$ Psorophora $;$ Or. $=$ Orthopodomyia $; \mathrm{Li} .=$ Limatus; $\mathrm{Tr} .=$ Trichoprosopon; Jb. = Johnbelkinia.

isolates. A total of $6 \mathrm{VEE}$ virus isolates was made from sentinel hamsters; no isolates were made from the trapped animals or mosquitoes. The viruses were characterized antigenically using monoclonal antibodies as described previously. ${ }^{16}$ All of the isolates had positive reactions to monoclonal antibodies 2A2C-3, 1A3B-7, 1A3A-9, 1A1B-9, and $1 \mathrm{~A} 4 \mathrm{D}-1$ and negative reactions to antibody $1 \mathrm{~A} 3 \mathrm{~A}-5$, indicating that they belonged to VEE subtype ID.

To examine the genetic relationships of the Miranda State virus isolates to other VEE complex strains including the 1983 Panaquire IC isolate, we sequenced a portion of the genome for one sentinel hamster isolate made during May and one from December 1997 (strains MAC-10 and MAC87 , respectively). These strains were selected to represent each of two different single stranded conformation polymorphism (SSCP) patterns detected among the 6 hamster isolates (Weaver $\mathrm{S}$, unpublished data). Complete sequences of 1,677 nucleotides covering the P62 gene were determined directly from RT-PCR amplicons and compared to homologous VEE complex sequences found in the GenBank li-

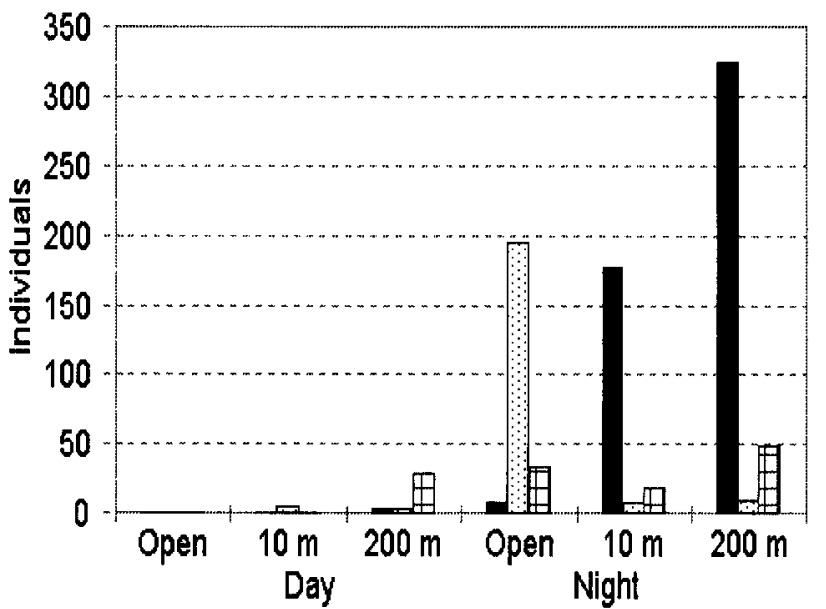

Cx. spissipes Ma titillans $\#$ Cx. mollis

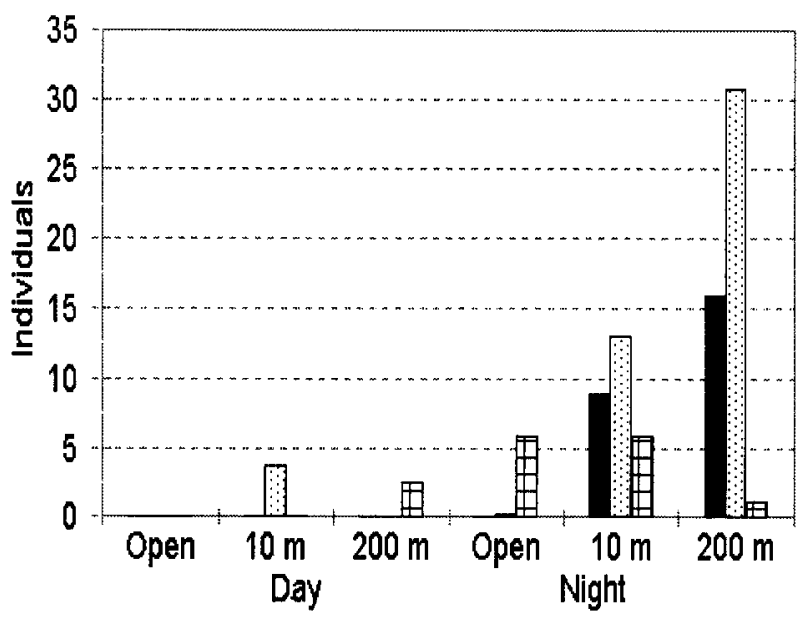

Cx.pedroi $\quad$ Cx. dunni $\quad$ Cx.nigripalpus

FIGURE 4. Numbers of representative mosquitoes captured in $\mathrm{CO}_{2}$-baited Centers for Disease Control and Prevention light traps outside the forest (open), as well as 10 and $200 \mathrm{~m}$ inside, during the day and at night. Cx. $=$ Culex; Ma. $=$ Mansonia .

brary. ${ }^{12,17,25-28}$ The Miranda isolates exhibited a minimum nucleotide sequence divergence of $8 \%$ (3\% divergence of deduced amino acid sequences) versus all other VEE complex viruses sequenced previously. Phylogenetic analyses using all methods generated trees with nearly identical topologies, with the exception of a minor difference in groupings within the subtype IAB clade in two equally parsimonious trees. Because the distance methods generate trees with branch lengths corrected for superimposed nucleotide substitutions, the tree generated using neighbor joining is shown in Figure 5. The Miranda isolates were most closely related to members of the VEE antigenic complex in subtype I, varieties $\mathrm{AB}, \mathrm{C}$ and $\mathrm{D}$, followed by Everglades virus in subtype II. The Miranda isolates represented a distinct lineage of subtype I viruses nested within the subtype IABCD clade. This clade included representatives of four previously recognized ID-like lineages: 1) ID strains from Tumaco, Colombia, and adjacent coastal Ecuador, 2) Everglades virus (subtype II) 


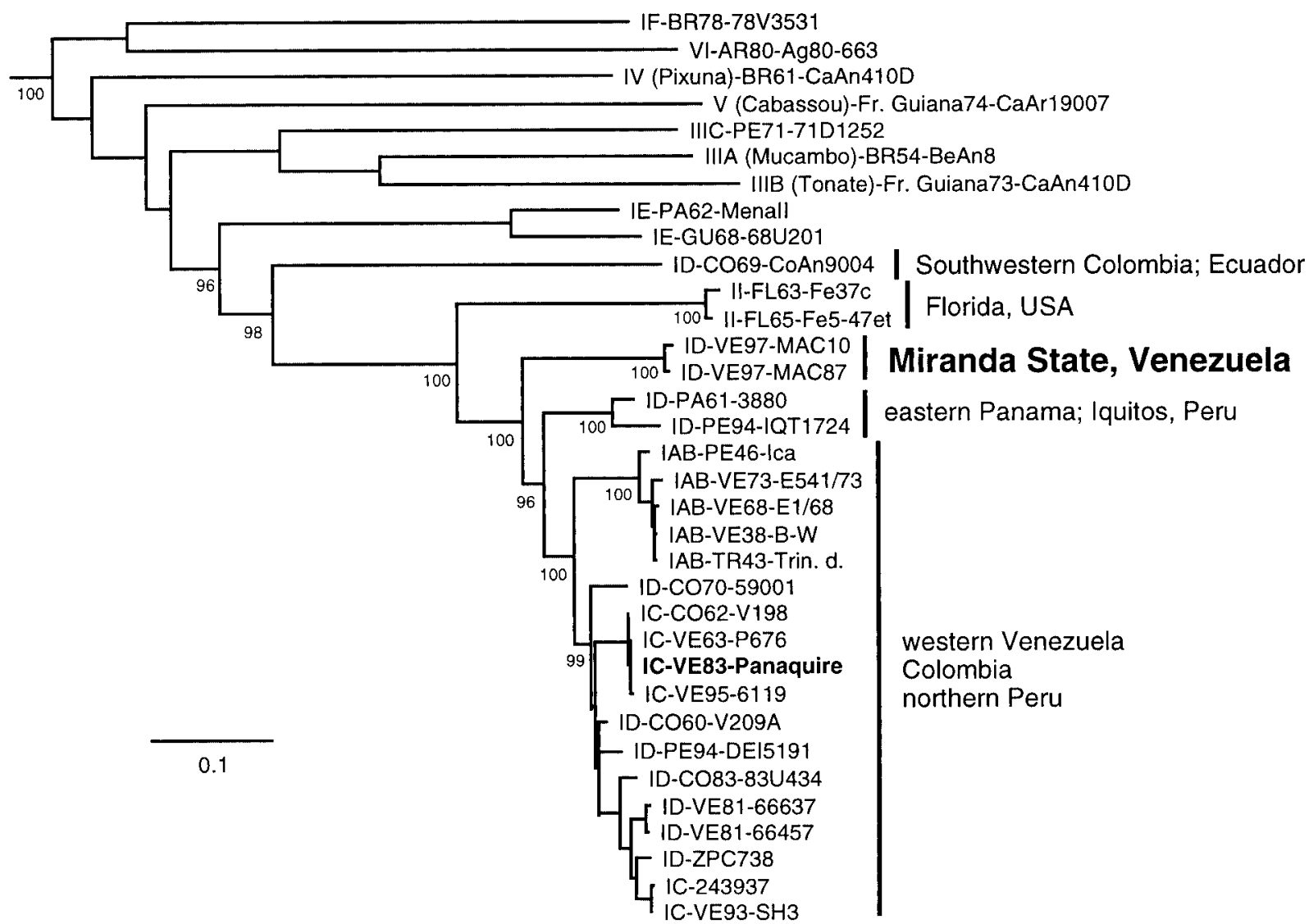

FIGURE 5. Phylogenetic tree generated using PE2 nucleotide sequences of two representative Miranda State isolates and homologous sequences from the GenBank library. The tree was constructed using the neighbor joining program and distances were generated using the F84 formula. Virus strains are designated by subtype, followed by country or Florida abbreviation, year, and strain name. Numbers indicate bootstrap values for groups to the right, and the scale indicates $10 \%$ nucleotide sequence divergence.

from Florida, 3) ID viruses from Panama and recent isolates from Iquitos, Peru, and 4) a clade comprised of three distinct lineages of IAB and IC epizootic viruses nested within a group of ID viruses from Venezuela, Colombia, and northern Peru. ${ }^{13}$ Thus, the Miranda isolates represent a fifth distinct lineage of ID-like VEE viruses. The relationships depicted by the trees indicated that, unlike other ID viruses from western Venezuela, the Miranda viruses are not linked to the emergence of any known VEE epizootics.

\section{DISCUSSION}

The results of this study indicate that VEE virus subtype ID is enzootic in a tropical rainforest that was converted into cacao plantations in the Padrón Agriculture Station in Miranda State, Venezuela. These results demonstrate the flexibility of VEE viruses and their hosts to adapt to anthropogenic change, in this case, forest alterations for the production of cacao.

Previous studies in Panaquire ${ }^{14}$ suggested that this region was a potential VEE focus. The sporadic isolation of VEE virus during 1997-1998, and the HI antibodies in small mammals during an interepidemic period suggest that these viruses are transmitted continuously or semicontinuously at low levels and become amplified during certain periods of the year when ecological conditions are favorable. The ab- sence of antibodies in humans, even in persons at high risk of VEE ID virus infection due to their work within the cacao plantation where virus circulation was detected, suggest that the virus is not regularly transmitted to humans by enzootic vectors. This could reflect a nocturnal feeding periodicity of the principal enzootic vector species, or a non-anthropophilic host preference of the vector(s). Incrimination of the enzootic vector(s) at this site will require further studies. However, two abundant members of the Spissipes Section of the subgenus Culex (Melanoconion), the taxon containing all established enzootic VEE virus vectors, ${ }^{1}$ are likely candidates: Cx. (Mel.) pedroi and Cx. (Mel.) spissipes.

The previous isolation of a subtype IC VEE virus (Panaquire strain $)^{14}$ that is genetically very similar to strains isolated during major VEE outbreaks in the 1960s and 1995 suggested interepidemic circulation of a subtype IC virus in this region. However, the viruses we isolated from the Miranda cacao plantation are relatively distantly related both antigenically and genetically to the Panaquire strain and other subtype IC isolates. If an IC virus is still circulating in this region, it must be in other locations or transmitted at an undetectably low level. Surveillance in this region of Miranda State, assisted by satellite imagery, has not revealed the presence of any extensive, primary lowland tropical forests or swamps like those known to support continuous transmission of VEE viruses in other locations of South Ameri- 
ca. ${ }^{15,29-34}$ Studies are now underway to locate such a transmission cycle in Falcon State, where the 1995 outbreak began.

Previous field studies of enzootic VEE virus ecology implicated small mammals as reservoir hosts. In Panama, cotton rats (Sigmodon hispidus) and spiny rats (Proechimys semispinosus) were implicated based on antibody rates and detection of natural viremia, ${ }^{35,36}$ as well as on the high-titered viremia generated after experimental infections. ${ }^{37}$ In Florida, S. hispidus and Peromyscus gossypinus were implicated as important reservoirs. ${ }^{38}$ Other mammals, such as opossums (Didelphis marsupialis) are also frequently infected with enzootic VEE viruses in a variety of locations. ${ }^{30,31,39-41}$ The high rate of VEE virus antibodies we found in Proechimys guair$a e$ is consistent with the conclusions of previous studies that these spiny rats are important reservoir hosts of enzootic VEE viruses.$^{37}$ We also detected antibodies in two Didelphis marsupialis, consistent with previous results in Venezuela. ${ }^{30,31}$ To our knowledge, Marmosa spp. have not previously been implicated as enzootic reservoirs of VEE virus. In our study, Marmosa spp. was one of the most abundant animals captured. In previous studies with subtype IE VEE viruses, experimentally infected Didelphis marsupialis generated viremia of up to $10^{4.5}$ suckling mouse intracerebral $\mathrm{LD}_{50} / \mathrm{ml} .^{39}$ Experimental infections are needed to determine if Didelphis marsupialis, and Marmosa spp. produce adequate viremia to be important reservoir hosts of subtype ID viruses.

Recent phylogenetic studies have revealed close evolutionary relationships among some epizootic and enzootic VEE viruses and have implicated mutation of subtype ID strains in VEE emergence. The best examples of the enzootic-epizootic connection are subtype ID viruses isolated in western Venezuela and epizootic subtype IC strains from a small 1992-1993 outbreak in the same region. ${ }^{6,12,13}$ The subtype ID viruses we isolated during 1997 in Miranda State, Venezuela are more distantly related to all epizootic strains than are the ID isolates from western Venezuela (Figure 5). Surprisingly, these Miranda viruses are even more distantly related to epizootic strains than other subtype ID isolates from Panama and Peru. These comparisons indicate that the viruses we isolated in this study are not linked to epizootic emergence. They represent a fifth major genotype of ID-like VEE virus that occur in geographically non-overlapping distributions: 1) northern Peru, Colombia and western Venezuela; 2) Panama and the Amazon basin of Peru; 3) Miranda State in north central Venezuela; 4) Florida (Everglades virus) and 5) southwestern Colombia and coastal Ecuador ${ }^{1}$ (Figure 5). The reason that only the first ID genotype is linked to epizootic emergence could be related to the genetic background of the enzootic precursors and their ability to generate appropriate combinations of epizootic mutations, and/or different ecological conditions in locations 2-5, with different capacities for epizootic amplification. However, the history of extensive VEE epizootics in Miranda State, Venezuela, and Coastal Ecuador does not support the latter hypothesis. Reverse genetic studies using infectious cDNA clones will ultimately be needed to assess the ability of different enzootic strains of VEE virus to generate epizootics via mutation.

Acknowledgments: This study was supported by the Ministerio de
Sanidad y Asistencia Social based on the Dengue National Surveillance Program. We thank Pedro Sanchez and field personnel from the Padrón Agriculture Station for logistical support, and Nieves Torres for plant species identifications. Ann Powers kindly assisted with preparation of the manuscript.

Financial support: This research was supported by NIH grant AI39800, the National Aeronautics and Space Administration (NASA), and the World Bank.

Authors' addresses: Rosa Alba Salas, Clovis Vasquez, Instituto Nacional de Higiene, Caracas, Venezuela. Roberto Barrera and Juan Carlos Navarro, Instituto de Zoologia Tropical, Universidad Central de Venezuela, Caracas, Venezuela. Gladys Medina, Instituto de Investigaciones Veterinarias, Av. Principal de las Delicias, Maracay, Venezuela. Scott C. Weaver, Center for Tropical Diseases and Department of Pathology, University of Texas Medical Branch, Galveston, Texas 77555-0609.

Reprint requests: Scott Weaver, Department of Pathology, University of Texas Medical Branch, 301 University Blvd., Galveston, Texas 77555-0609.

\section{REFERENCES}

1. Weaver SC, 1998. Recurrent emergence of Venezuelan equine encephalomyelitis. Scheld WM, Hughes J, eds. Emerging Infections I. Washington, DC: ASM Press, 27-42.

2. Johnson KM, Martin DH, 1974. Venezuelan equine encephalitis. Adv Vet Sci Comp Med 18: 79-116.

3. Walton TE, Grayson MA, 1988. Venezuelan equine encephalomyelitis. Monath TP, ed. The Arboviruses: Epidemiology and Ecology, Vol. IV. Boca Raton, Florida: CRC Press, 203233.

4. Kubes V, Rios FA, 1939. The causative agent of infectious equine encephalomyelitis in Venezuela. Science 90: 20-21.

5. Lord RD, 1974. History and geographic distribution of Venezuelan equine encephalitis. Bull PAHO 8: 100-110.

6. Rico-Hesse R, Weaver SC, de Siger J, Medina G, Salas RA, 1995. Emergence of a new epidemic/epizootic Venezuelan equine encephalitis virus in South America. Proc Natl Acad Sci USA 92: 5278-5281.

7. Oberste MS, Fraire M, Navarro R, Zepeda C, Zarate ML, Ludwig GV, Kondig JF, Weaver SC, Smith JF, Rico-Hesse R, 1998. Association of Venezuelan equine encephalitis virus subtype IE with two equine epizootics in Mexico. Am J Trop Med Hyg 59: 100-107.

8. Watts DM, Callahan J, Rossi C, Oberste MS, Roehrig JT, Wooster MT, Smith JF, Cropp CB, Gentrau EM, Karabatsos N, Gubler D, Hayes CG, 1998. Venezuelan equine encephalitis febrile cases among humans in the Peruvian Amazon River region. Am J Trop Med Hyg 58: 35-40.

9. Weaver SC, Salas R, Rico-Hesse R, Ludwig GV, Oberste MS, Boshell J, Tesh RB, 1996. Re-emergence of epidemic Venezuelan equine encephalomyelitis in South America. Lancet 348: 436-440.

10. Rivas F, Diaz LA, Cardenas VM, Daza E, Bruzon L, Alcala A De la Hoz O, Caceres FM, Aristizabal G, Martinez JW, Revelo D, De la Hoz F, Boshell J, Camacho T, Calderon L, Olano VA, Villarreal LI, Roselli D, Alvarez G, Ludwig G, Tsai T, 1997. Epidemic Venezuelan equine encephalitis in La Guajira, Colombia, 1995. J Infect Dis 175: 828-832.

11. Calisher CH, Karabatsos N, 1988. Arbovirus serogroups: Definition and geographic distribution. Monath TP, ed. The Arboviruses: Epidemiology and Ecology, Vol. I. Boca Raton, FL: CRC Press, 19-57.

12. Wang E, Barrera R, Boshell J, Ferro C, Freier JE, Navarro JC, Salas R, Vasquez C, Weaver SC, 1999. Genetic and phenotypic changes accompanying the emergence of epizootic subtype IC Venezuelan equine encephalitis viruses from an enzootic subtype ID progenitor. J Virol 73: 4266-4271.

13. Powers AM, Oberste MS, Brault AC, Rico-Hesse R, Schmura SM, Smith JF, Kang W, Sweeney W, Weaver SC, 1997. Repeated emergence of epidemic/epizootic Venezuelan equine 
encephalitis from a single genotype of enzootic subtype ID virus. J Virol 71: 6697-6705.

14. Querales J, Plaz J, Fernandez H, Acive F, 1985. Estudio seroepidemiologico de encefalitis por virus Venezolano en la zona de Barlovento. Rev Inst Nacional de Hygiene "Rafael Rangel" 18: 43-49.

15. Dickerman RW, Cupp EW, Groot H, Alarcon AM, Cura E, Dickerman AW, Ibagos AL, Rico-Hesse R, Taylor CA, Weaver SC, 1986. Venezuelan equine encephalomyelitis virus activity in northern Colombia during April and May 1983. PAHO Bull 20: 276-283.

16. Roehrig JT, Bolin RA, 1997. Monoclonal antibodies capable of distinguishing epizootic from enzootic varieties of Subtype I Venezuelan equine encephalitis viruses in a rapid indirect immunofluorescence assay. J Clin Microbiol 35: 1887-1890.

17. Weaver SC, Pfeffer M, Marriott K, Kang W, Kinney RM, 1999. Genetic evidence for the origins of Venezuelan equine encephalitis virus subtype IAB outbreaks. Am J Trop Med Hyg 60: $441-448$.

18. Devereux J, Haeberli P, Smithies O, 1984. A comprehensive set of sequence analysis programs for the VAX. Nucleic Acids Res 12: 387-395.

19. Swofford DL, 1998. PAUP*. Phylogenetic Analysis Using Parsimony (*and Other Methods). Version 4. Sunderland, MA: Sinauer Associates.

20. Cilnis MJ, Kang W, Weaver SC, 1996. Genetic conservation of Highlands J viruses. Virology 218: 343-351.

21. Weaver SC, Kang W, Shirako Y, Rumenapf T, Strauss EG, Strauss JH, 1997. Recombinational history and molecular evolution of western equine encephalomyelitis complex alphaviruses. J Virol 71: 613-623.

22. Weaver SC, Bellew LA, Hagenbaugh A, Mallampalli V, Holland JJ, Scott TW, 1994. Evolution of alphaviruses in the eastern equine encephalomyelitis complex. $J$ Virol 68: 158-169.

23. Felsenstein J, 1985. Confidence limits on phylogenies: An approach using the bootstrap. Evolution 39: 783-791.

24. Brault AC, Powers AM, Chavez CL, Lopez RN, Cachon MF, Gutierrez LF, Kang W, Tesh RB, Shope RE, Weaver SC, 1999. Genetic and antigenic diversity among eastern equine encephalitis viruses from North, Central, and South America. Am J Trop Med Hyg 61: 579-586.

25. Kinney RM, Pfeffer M, Tsuchiya KR, Chang GJ, Roehrig JT, 1998. Nucleotide sequences of the 26S mRNAs of the viruses defining the Venezuelan equine encephalitis antigenic complex. Am J Trop Med Hyg 59: 952-964.

26. Oberste MS, Parker MD, Smith JF, 1996. Complete sequence of Venezuelan equine encephalitis virus subtype IE reveals conserved and hypervariable domains within the $\mathrm{C}$ terminus of nsP3. Virology 219: 314-320.

27. Kinney RM, Johnson BJB, Welch JB, Tsuchiya KR, Trent DW, 1989. Full-length nucleotide sequences of the virulent Trinidad donkey strain of Venezuelan equine encephalitis virus and its attenuated derivative, strain TC83. Virology 170: 19-31.

28. Sneider J, Kinney R, Tsuchiya K, Trent D, 1993. Molecular evidence that epizootic Venezuelan equine encephalitis (VEE)
I-AB viruses are not evolutionary derivatives of enzootic VEE subtype I-E or II viruses. J Gen Virol 74: 519-523.

29. Walder R, Suarez OM, 1976. Studies of arboviruses in southwestern Venezuela: I. Isolations of Venezuelan and eastern equine encephalitis viruses from sentinel hamsters in the $\mathrm{Ca}$ tatumbo region. Int J Epidemiol 5: 375-384.

30. Walder R, Suarez OM, Calisher CH, 1984. Arbovirus studies in the Guajira region of Venezuela: activities of eastern equine encephalitis and Venezuelan equine encephalitis viruses during an interepizootic period. Am J Trop Med Hyg 33: 699707.

31. Walder R, Suarez OM, Calisher CH, 1984. Arbovirus studies in southwestern Venezuela during 1973-1981. II. Isolations and further studies of Venezuelan and eastern equine encephalitis, Una, Itaqui, and Moju viruses. Am J Trop Med Hyg 33: 483491.

32. Causey OR, Causey CE, Maroja OM, Macedo DG, 1961. The isolation of arthropod-borne viruses, including members of hitherto undescribed serological groups, in the Amazon region of Brazil. Am J Trop Med Hyg 10: 227-249.

33. Shope RE, Causey OR, Homobono Paes de Andrade A, Theiler M, 1964. The Venezuelan equine encephalomyelitis complex of group A arthropod-borne viruses, including Mucambo and Pixuna from the Amazon region of Brazil. Am J Trop Med Hyg 13: 723-727.

34. Aitken THG, 1972. Habits of some mosquito hosts of VEE (Mucambo) virus from northeastern South America, including Trinidad. Proceedings of the Workshop-Symposium on Venezuelan Encephalitis Virus. Washington, DC: Pan American Health Organization, 254-256.

35. Grayson MA, Galindo P, 1968. Epidemiologic studies of Venezuelan equine encephalitis virus in Almirante, Panama. Am J Epidemiol 88: 80-96.

36. Grayson MA, Galindo P, 1969. Ecology of Venezuelan equine encephalitis virus in Panama. J Am Vet Med Assoc 155: 21412145

37. Young NA, Johnson KM, Gauld LW, 1969. Viruses of the Venezuelan equine encephalomyelitis complex. Experimental infection of Panamanian rodents. Am J Trop Med Hyg 18: 290296.

38. Chamberlain RW, Sudia WD, Work TH, Coleman PH, Newhouse VF, Johnson JG Jr, 1969. Arbovirus studies in south Florida, with emphasis on Venezuelan equine encephalomyelitis virus. Am J Epidemiol 89: 197-210.

39. Scherer WF, Dickerman RW, La Fiandra RP, Wong Chia C, Terrian J, 1971. Ecologic studies of Venezuelan encephalitis virus in southeastern Mexico. IV. Infections of wild mammals. Am J Trop Med Hyg 20: 980-988.

40. Galindo P, 1972. Endemic vectors of Venezuelan encephalitis. Proceedings of the Workshop-Symposium on Venezuelan Encephalitis Virus. Washington, DC: Pan American Health Organization, 249-253.

41. Navarro JC, Walder R, Suárez OM, Decena CM, Garzaro D, Montañez H, Barrios M, 1992. Didelphis marsupialis como posible reservorio de algunos Alpha y Flavivirus. Importancia del Didelphis marsupialis en Salúd Pública. Mérida, (Merida) Venezuela: Consejo de Publicaciones de la Universidad de Los Andes, 31-36. 